\title{
PERLINDUNGAN NASABAH REKSA DANA PADA KELALAIAN PENEMPATAN DANA OLEH MANAJER INVESTASI
}

\author{
Ruth Livya Maryann Tilaar* \\ Program Studi Magister Kenotariatan, Fakultas Hukum, Universitas Surabaya
}

\begin{abstract}
Basic human needs include clothing, food and shelter which in its fulfillment certainly requires sufficient funds to be able to buy what each individual needs and wants. Every year there is always an increase in inflation in every product and service consumed by the public. the value of money decreases over time due to inflation. This value of money can be maintained one of them by diversifying investments in different investment instruments and there are even investments whose results can be used to meet short-term or long-term needs but the investment itself can also be used to make a profit. indirect investment in the form of Mutual Funds because in this investment the purchase is made by an Investment Manager in a security that sells Mutual Funds. This research is a normative research with a law and case study approach. This study revealed that investment diversification in mutual funds was carried out because it was easier and helped by the role of investment managers who made portfolio selection. Risk looms especially with regard to the incidence of losses in investing due to the manager's expertise. Mainly caused by the lack of ability to choose the contents of the portfolio and the lack of sensitivity of Investment managers to market changes. Therefore the role of the government is needed in anticipating the irresponsible behavior of the Investment Manager by providing legal rules and sanctions for the Investment Manager and not forgetting to always provide socialization to the public to always be alert to the lure of rich quick and sure profits from parties who are not be responsible.
\end{abstract}

Keyword: mutual fund, investment manager, investment risk, default

\begin{abstract}
ABSTRAK
Kebutuhan dasar manusia melliputi sandang, pangan dan papan dimana dalam pemenuhannya tentu membutuhkan dana yang cukup untuk bisa membeli apa yang masing-masing individu butuhkan dan inginkan. Setiap tahun selalu ada kenaikan inflasi pada setiap produk maupun jasa yang dikonsumsi oleh masyarakat. nilai uang menurun seiring waktu akibat inflasi. Nilai uang ini bisa dijaga salah satunya dengan melakukan diversifikasi investasi pada instrumen investasi yang berbeda bahkan ada juga investasi yang hasilnya bisa digunakan untuk memenuhi kebutuhan jangka pendek ataupun jangka panjang tetapi investasi sendiri juga bisa digunakan untuk memperoleh keuntungan. investasi tidak langsung berupa Reksa Dana karena pada investasi ini pembelian dilakukan oleh Manajer Investasi pada sekuritas yang menjual Reksa Dana. Penelitian ini merupakan penelitian normatif dengan pendekatan undang-undang dan case study. Penelitian ini mengungkap bahwa diversifikasi investasi pada reksadana dilakukan karena lebih mudah dan terbantu dengan peran manajer investasi yang melakukan pemilihan isi portofolio. Risiko yang membayangi terutama dengan kaitan timbulnya kerugian dalam berinvestasi karena keaplaan Manajer pun besar. Terutama diakibatkan oleh minimnya kemapuan memilih isi portofolio dan kurang pekanya manajer Investasi terhadap perubahan pasar. Maka dari itu dibutuhkan peranan dari pemerintah dalam mengantisipasi perbuatan tidak bertanggungjawab Manajer Investasi dengan menyediakan aturan hukum serta sanksi bagi Manajer Investasi dan tidak lupa untuk selalu memberikan sosialisasi kepada masyarakat untuk
\end{abstract}


selalu waspada terhadap iming-iming kaya cepat dan pasti untung dari pihak-pihak yang tidak bertanggugjawab.

Kata Kunci: Reksadana, Manajer Investasi, Risiko Investasi, Gagal Bayar

\section{A. PENDAHULUAN}

\subsection{Latar Belakang}

Kebutuhan dasar manusia melliputi sandang, pangan dan papan dimana dalam pemenuhannya tentu membutuhkan dana yang cukup untuk bisa membeli apa yang masing-masing individu butuhkan dan inginkan. Setiap tahun selalu ada kenaikan inflasi pada setiap produk maupun jasa yang dikonsumsi oleh masyarakat. Berdasarkan keterangan Bank Indonesia pada bulan November 2019 tingkat inflasi secara mencapai $3 \%{ }^{1}$. Inflasi merupakan kenaikan harga secara umum dan terus menerus pada jangka waktu tertentu. Contoh sederhana inflasi adalah naiknya harga komoditas pangan setiap tahun $^{2}$, tentu harga beras, telur, minyak goreng elalu merangkak naik bahkan hampir di setiap peringatan hari keagamaan harga komoditas ini bisa dipastikan naik. Meningkatnya harga

kebutuhan dasar manusia ini seringkali tidak dikuti dengan meningkatnya daya beli masyarakat, nilai uang seratus ribu rupiah dulu bisa untuk membeli beras 20 kilogram tetapi kini hanya bisa untuk membeli 10 kilogram beras. Dari sini kita bisa mengetahui bahwa nilai uang menurun seiring waktu akibat inflasi. Nilai uang ini bisa dijaga salah satunya dengan melakukan diversifikasi investasi pada instrumen investasi yang berbeda bahkan ada juga investasi yang hasilnya bisa digunakan untuk memenuhi kebutuhan jangka pendek ataupun jangka panjang tetapi investasi sendiri juga bisa digunakan untuk memperoleh keuntungan. Investasi adalah komitmen atas sejumlah dana atau sumber daya lainnya yang dilakukan pada saat ini, dengan tujuan memperoleh sejumlah keuntungan dimasa datang. ${ }^{3}$ Investasi bisa dilakukan pada aset finansial dan investasi pada aset ril berupa tanah, pabrik, dan lain-lain.

Investasi pada aset finansial dibagi menjadi dua jenis yaitu investasi langsung dan tidak langsung, Beberapa bentuk instrumen investasi langsung yang dikenal oleh masyarkat yaitu deposito, emas, obligasi dan saham. Sedangkan untuk investasi tidak langsung berupa Reksa Dana karena pada investasi ini pembelian dilakukan oleh Manajer Investasi pada sekuritas yang menjual Reksa Dana. Masing-masing dari
1 Bank Indonesia. (2018). Pengertian Inflasi. https://www.bi.go.id/id/moneter/inflasi/data/Def ault.aspx. diakses tanggal 24 November 2019 jam 12.10 WIB

${ }^{2}$ Bank Indonesia. (2019). Laporan Inflasi (Indeks Harga Konsumen) Berdasarkan Perhitungan Inflasi Tahunan. https://www.bi.go.id/id/moneter/inflasi/pengenal an/Contents/Default.aspx. diakses tanggal 24 November 2019 jam 13.00 WIB.

${ }^{3}$ Eduardus Tendelilin. (2001). Analisis Investasi dan Manajemen Portofolio. Edisi I. cet. I. Yogyakarta: BPFE. hal: 1. 
instrumen ini memiliki kelebihan dan dan kekurangan serta resiko yang berbeda. pada investasi Reksadana nasabah hanya bisa memilih jenis reksadana yang diinginkan sedangkan nasabah tidak bisa memilih isi portofolio karena sudah dipilihkan oleh Manajer investasi, hal ini tentu berbeda dengan investasi langsung ke dalam instrumen saham, emas, obligasi dan deposito yang bisa dilakukan secara mandiri. Pemilihan instrumen investasi berbentuk reksadana biasanya dipilih oleh nasabah yang tidak ingin kesulitan mengelolah portofolionya karena semua keputusan ada di tangan Manajer Investasi, nasabah tidak perlu memantau terus menerus portofolio miliknya, dan dengan modal minim nasabah pun bisa berinvestasi karena sifat reksadana yang kolektif.

Selain itu ada juga nasabah yang kurang memahami bagaimana kinerja dari reksadana yang dibeli dan kinerja manajer investasinya sehingga nasabah memilih untuk percaya saja. Hal ini menjadi kesempatan bagi para oknum tidak bertanggungjawab untuk melakukan kejahatan sehingga menimbulkan kerugian bagi nasabah. Contoh kasus yang saat ini sedang hangat adalah permasalahan pada produk reksadana yang dikeluarkan oleh Narada Asset Management (NAM) dan Minna Padi Asset Management (MPAM).
Kinerja dua produk milik NAM yaitu Narada Saham Indonesia dan Narada Campuran 1 terjun bebas sejak 4 November 2019 hal ini kemudian direspon oleh Otoritas Jasa Keuangan selaku regulator pada Pasar Modal dengan melakukan suspensi atau penghentian sementara untuk produk ini mulai 15 November $2019^{4}$ melalui Surat Perintah Untuk Melakukan Tindakan tertentu. Dua produk NAM ini mengalami gagal bayar karena portofolio yang dikelolahnya anjlok sebanyak $48 \%$.

Suspensipun dialami oleh MPAM dimana perusahaan ini menjanjikan keuntungan yang pasti pada Reksadana saham yang sebenarnya nilainya bisa sangat fluktuatif. Sanksi berupa suspensi tertuang pada Surat Perintah Otoritas Jasa Keuangan No S1240/PM.21/2019.5 Suspensi ini akan membatasi pembuatan Reksadana baru, kontrak pengelolaan efek nasabah baru dan unit baru penjualan produk yang telah terbit dan dikelolah MPAM. Ada dua produk yang dianggap melanggar ketentuan penjualan dengan menjanjikan keuntungan pasti pada calon nasabah Reksadana Minna Padi Pasopati Saham dan Reksadana Minna Padi Pringgodani Saham dengan menjanjikan return kurang lebih $11 \%$.

Berinvestasi dalam produk yang berkaitan dengan saham akan selalu tergantung pada kondisi Makro
4 Yudho, Winarto. (2019). Ini Penyebab Bareksa Suspensi Dua Reksadana Narada Aset Manajemen. https://investasi.kontan.co.id/news/ini-penyebabbareksa-suspensi-dua-reksadana-narada-asetmanajemen?page=all/. diakses tanggal 4 Desember 2019 jam 22.23 WIB.
${ }^{5}$ Tahir S, Irvin A. (2019). Janjikan Return, OJK Suspensi Penjualan Reksa Dana Minna Padi. https://www.cnbcindonesia.com/investment/2019 1012173851-21-106514/janjikan-return-ojksuspensi-penjualan-reksa-dana-minna-padi. diakses tanggal 4 Desember 2019 pada jam 22.42 WIB. 
Ekonomi serta kondisi global. maka dari itu Penelitian ini akan berfokus pada instrumen investasi Reksa Dana, dimana ditemukannya kasus gagal bayar pada perusahaanperusahaan Aset manajemen yang menjual produk reksadana serta adanya iming-iming mendapatkan keuntungan pasti, sehingga menjadi penting bagi masyarkat untuk memahami perlindungan hukum bagi nasabah yang dirugikan dan diharapkan bisa mencegah terjadinya hal serupa dengan lebih bijak dan berhati-hati dalam memilik instrumen investasi terutama Reksa Dana.

\subsection{Rumusan Masalah}

\section{Apakah yang dimaksud dengan reksa dana?}

2. Bagaimanakah perlindungan nasabah pada produk reksadana?

\subsection{Tujuan}

1. Memahami apa itu reksa dana

2. Mengetahui perlindungan bagi nasabah reksa dana

\section{B. METODE PENELITIAN}

Metode penelitian ini merupakan penelitian normatif yang menggunakan studi kasus komparatif melalui pengkajian undang-undang dengan menjadikan pokok kajian berupa hukum yang dikonsepkan sebagai norma atau kaidah. Penelitian ini berfokus pada investarisasi hukum positif, asas dan doktrin hukum, penemuan hukum, sistematik hukum, perbandingan hukum. ${ }^{6}$ pendekatan yang digunakan dalam penelitian ini adalah pendekatan peraturan perundang-undangan

(statue approach) dan case study. ${ }^{7}$

C. PEMBAHASAN

\section{Pengertian Reksadana}

Reksa Dana berdasarkan Undang-undang Pasar Modal Nomor 8 Tahun 1995 (UU Pasar Modal) Pasal 1 Ayar 27 merupakan wadah yang digunakan untuk menghimpun dana dari masyarakat pemodal yang kemudian diinvestasikan pada portofolio efek oleh Manajer Investasi. Perusahaan investasi ini kemudian mengelolah uang dari masyarakat baik yang berbentuk lembaga investor maupun dari investor perorangan atau ritel ke dalam media investasi, baik di pasar modal, pasar uang maupun lainnya. pengertian Manajer investasi menurut UU Pasar Modal Pasal 1 angka 11 merupakan pihak yang kegiatan usahanya adalah untuk mengelolah portofolio efek para nasabah atau mengelola portofolio investasi kolektif untuk sekelompok nasabah, kecuali perusahaan asuransi, dana pensiun dan bank yang melakukan sendiri kegiatan usahanya berdasarkan peraturan perundang-undangan yang berlaku. Dalam berinvestasi ada istilah High Risk High Return, low risk low return yang berarti risiko yang besar akan mendapatkan keuntungan yang besar, begitu pula dengan risiko

\footnotetext{
6 Abdulkadir, Muhammad. (2004). Hukum dan Penelitian Hukum. Cet. 1. Bandung: PT Citra Aditya Bakti. hal: 52.
}

\footnotetext{
${ }^{7}$ Peter Mahmud, Marzuki. Penelitian Hukum. Cet.2.
} Jakarta: Kencana. hal: 29. 
kecil maka keuntungan juga akan kecil.

Pembelian reksadana ini dilakukan oleh nasabah melalui Manajer Investasi dengan melakukan setoran pada Bank Kustodian sebelumnya nasabah akan diberikan pertanyaan untuk menentukan profil risiko nasabah dan pilihan investasi yang diinginkan oleh nasabah. Manajer Investasi ini akan mengelolah dana nasabah dengan melakukan pembelian dan/atau penjualan instrumen investasi pasar uang berupa Surat Berharga Bank indonesia, Deposito, Surat Berharga Pasar Uang maupun berupa obligasi dan saham. Ketika nasabah ingin untuk menjual reksadananya maka Manajer Investasi akan memberin instruksi pada Bank Kustodian untuk mengirimkan dana hasil penjualan kepada Investor. Dari sini kita bisa membagi 4 macam reksa dana berdasarkan risiko yang ada padanya dimulai dari yang paling kecil risikonya, yaitu: ${ }^{8}$
a. Reksa Dana Pasar Uang (RDPU)
b. Reksa Dana Pendapatan Tetap (RDPT)
c. Reksa Dana Campuran (RDC)
d. Reksa Dana Saham (RDS)

a. Reksa Dana Pasar Uang RDPU mirip dengan deposito dimana alokasi dana RDPU dimasukkan ke dalam instrumen yang jatuh tempo kurang dari satu tahun, reksadana ini mengalokasikan seluruh invetasinya ke dalam efek pasar uang berupa utang. Risiko dari reksa dana ini adalah yang paling rendah tetapi juga dengan imbal hasil yang rendah.

b. Reksa dana Pendapatan Tetap

RDPT ini menempatkan paling sedikit $80 \%$ dari portofolio kelolaan Manajer Investasi (MI) pada efek yang bersifat hutang, seperti oligasi. Risikonya setingkat lebih tinggi daripada RDPU

c. Reksa dana campuran RDC adalah reksadana yang investasinya ada pada efek ekuitas (saham) dan juga efek hutang (deposito maupun obligasi), risikonya lebih besar dibandingkan dengan RDPT mengingat alokasi investasi sebagian pada saham tetapi return atau imbal hasil juga lebih besar dibanding dengan dua reksadana sebelumnya.

d. Reksa dana saham

RDS adalah reksadana yang menginvestasikan paling sedikit $80 \%$ dari portofolio kelolaan MI pada efek ekuitas (saham). Dari saham ini akan memberikan imbal hasil yang lebih tinggi tapi mengingat saham yang sangat volatile maka risikonya pun menjadi lebih besar. Pendapatan dari RDS
8 Aini Masruroh Salam. (2014). Konsep Dasar Investasi Reksadana. Skripsi Untuk Meraih Gelar Sarjana Hukum Syariah, Universitas UIN, Jakarta.
Jurnal Filsafat dan Budaya Hukum. Vol.1, No.1, hal: 84-96. 
ini berupa capital gain dan deviden.

\section{Perlindungan Nasabah Pada Produk Reksadana}

Dalam melakukan kegiatan usaha reksadana tentu harus ada kesepakatan dan itikad baik dari para pihak baik itu Manajer Invetasi, Bank Kustodian dan nasabah selaku investor sehingga terjalin hubungan baik yang saling menguntungkan. Manajer Investasi pun dilarang untuk melakukan tindakan spekulasi maupun memberikan janji terhadap nasabah. Malanggar hal-hal ini tentu akan menimbulkan kerugian terutama terhadap nasabah yang memiliki dana. Perlu dipahami bahwa adamya keuntungan maupun kerugian dalam pembelian dan penjualan reksadana nasabah tetap harus membayar fee kepada Manajer Investasi, meskipun kemudian dikemudian hari ditemukan fakta bahwa kerugian tersebut diakibatkan oleh kelalaian Manajer Investasi dalam mengelolah dana nasabah selaku investor. Dalam berinvestasi tentu risiko terbesar yang bisa dialami oleh nasabah atau investor adalah hilangnya semua nilai investasi yang dimiliki.

Tentu saja dalam berinvestasi tidak akan luput dari risiko sehingga janji-janji keuntungan tanpa kerugian itu tidak mungkin ada selain merupakan tipu daya penjual produk investasi. Sebelumnya perlu dipahami risiko yang ada pada Instrumen investasi reksadana, yaitu: ${ }^{9}$

1. Turunnya Nilai Aktiva Bersih Unit penyertaan Reksadana mengalami penurunan nilai NAB unit penyertaan yang bisa disebabkan oleh Kinerja Bursa saham yang kurang baik, kinerja emiten yang tidak baik, kondisi politik dan ekonomi yang tidak stabli, kondisi global yang buruk, dan lain-lain

2. Risiko Likuiditas

Likuiditas adalah kemampuan perusahaan untuk bisa memenuhi kewajibannya dalam jangka pendek misal pembayaran utang yang bisa dibayarkan cepat, semakin baik kemampuan likuiditas perusahaan maka semakin kecil kemungkinannya untuk gagal bayar. Risiko likuiditas ini disebabkan oleh adanya penarikan dana besar-besaran terhadap Unit penyertaan Reksadana karena nasabah menganggap situasi politik dan ekonomi sedang kurang baik, emiten mengalami penutupan atau kebangkrutan, dan lainlain

3. Risiko Pasar

\footnotetext{
${ }^{9}$ Aini Masruroh, Op.cit. hal: 94-95.
} 


$\begin{array}{lr}\text { Risiko } & \text { pasar } \\ \text { dikarenakan } & \text { harga } \\ \text { instrumen investasi baik } \\ \text { berupa pasar } & \text { uang } \\ \text { maupun pasar } & \text { modal } \\ \text { mengalami penurunan } & \\ \text { secara drastis atau } & \text { ara } \\ \text { mengalami bearish. } & \text { behingga secara tidak } \\ \text { Sehingang } & \text { akan } \\ \text { langsung } & \text { mengakibatkan NAB } \\ \text { mengalami penurunan. }\end{array}$

4. Risiko Default

Risiko default adalah risiko yang timbul terhadap kegagalan pemenuhan kewajiban sebagaimana yang telah disepakati. Risiko ini ada pada obligasi korporasi, dimana obligasi korporasi ini tidak dijamin oleh pemerintah sebagai debitur. ${ }^{10}$

Kemampuan

Manajer Investasi bisa dilihat dari kemampuan memilih saham dan pilihan saham yang ia tetapkan untuk dimasukkan dalam portofolio investasinya ${ }^{11}$ hal ini berlaku jika portofolionya merupakan Reksadana Campuran maupun Reksadana Saham. Dalam melakukan perlindungan terhadap nasabah reksadana perlu adanya kebijakan pemerintah dalam menentukan standar kemampuan Manajer Investasi yang ditetapkan berdasarkan aturan hukum yang berlaku di Indonesia karena tidak semua MI memiliki kemampuan untuk menentukan waktu yang tepat kapan untuk membeli maupun menjual yang bila ternyata terlambat menyadari keadaan pasar akan merugikan pada nasabah. Nasabah selaku investor tentu juga perlu untuk memahami trend pasar dan instrumen reksadana tersebut dan tidak hanya menyerahkan segala keputusan kepada Manajer Investasi meskipun segala keputusan isi portofolio ditetukan oleh Manajer Investasi investor juga harus menganalisis dan memonitor kondisi pasar

\section{KESIMPULAN}

Berdasarakan penelitian diatas bisa disimpulkan bahwa masyarakat ketika melakukan investasi pada produk reksadana didasarkan atas keinginan nasabah untuk melakukan diversifikasi investasi selain investasi berbentuk emas dan deposito tetapi merasa kurang memahami investasi pada saham dan obligasi sehingga memutuskan untuk menggunakan reksadana, karena lebih mudah dan terbantu dengan peran manajer investasi

\footnotetext{
${ }^{10}$ Invovesta Beyond Data. (2019). Resiko Investasi. https://www.infovesta.com/index/learning/learnin g;jsessionid=C6DE4EAD651433CD34DC68373E2A3 876.NGXA/40. diakses tanggal 7 Desember 2019 jam 17.50 WIB.
}

\footnotetext{
${ }^{11}$ Michael Vincentius Panjaitan. (2012). Analisis Kemampuan Stock Selection dan Market Timing Manajer Investasi pada Reksadana Saham di Indonesia. Jurnal IImiah Mahasiswa Manajemen. Vol 1, No 2, hal: 1.
} 
yang melakukan pemilihan isi portofolio. Hal inipun tidak lepas dari risiko yang membayangi terutama dengan kaitan timbulnya kerugian dalam berinvestasi karena keaplaan Manajer Investasi yang diakibatkan oleh minimnya kemapuan memilih isi portofolio dan kurang pekanya manajer Investasi terhadap perubahan pasar. Maka dari itu dibutuhkan peranan dari pemerintah dalam mengantisipasi perbuatan tidak bertanggungjawab Manajer Investasi dengan menyediakan

\section{DAFTAR PUSTAKA}

\section{Daftar Buku}

Abdulkadir, Muhammad. (2004). Hukum dan Penelitian Hukum. Cet. 1. Bandung: PT Citra Aditya Bakti. hal: 52.

Peter Mahmud, Marzuki. Penelitian Hukum. Cet.2. Jakarta: Kencana. hal: 29.

Eduardus Tendelilin. (2001). Analisis Investasi dan Manajemen Portofolio. Edisi I. cet. I. Yogyakarta: BPFE. hal: 1 .

\section{Perundang-undangan}

Undang-undang Nomor 8Tahun 1995 tentang Pasar Modal

\section{Jurnal}

Aini Masruroh Salam. (2014). Konsep Dasar Investasi Reksadana. Skripsi Untuk Meraih Gelar Sarjana Hukum Syariah, Universitas UIN, Jakarta. Jurnal Filsafat dan Budaya Hukum. Vol.1, No.1, hal: 8496.

Michael Vincentius Panjaitan. (2012). Analisis Kemampuan Stock Selection dan Market Timing Manajer Investasi pada Reksadana Saham di Indonesia. Jurnal Ilmiah Mahasiswa Manajemen. Vol 1, No 2, hal: 1 .

\section{Website}

aturan hukum serta sanksi bagi Manajer Investasi dan tidak lupa untuk selalu memberikan sosialisasi kepada masyarakat untuk selalu waspada terhadap iming-iming kaya cepat dan pasti untung dari pihak-pihak yang tidak bertanggugjawab. Nasabah sendiri tidak boleh apatis dan harus selalu mampu menganalisis dan memonitor kondisi pasar dan tidak percaya $100 \%$ kepada Manajer Investasi.

Bank Indonesia. (2018). Pengertian Inflasi. https://www.bi.go.id/id/moneter/inflasi/dat a/Default.aspx. diakses tanggal 24 November 2019 jam 12.10 WIB

Bank Indonesia. (2019). Laporan Inflasi (Indeks Harga Konsumen) Berdasarkan Perhitungan Inflasi Tahunan. https://www.bi.go.id/id/moneter/inflasi/pen genalan/Contents/Default.aspx. diakses tanggal 24 November 2019 jam 13.00 WIB.

Yudho, Winarto. (2019). Ini Penyebab Bareksa Suspensi Dua Reksadana Narada Aset Manajemen. https://investasi.kontan.co.id/news/inipenyebab-bareksa-suspensi-duareksadana-narada-asetmanajemen?page $=$ all $/$. diakses tanggal 4 Desember 2019 jam 22.23 WIB.

Tahir S, Irvin A. (2019). Janjikan Return, OJK Suspensi Penjualan Reksa Dana Minna Padi. https://www.cnbcindonesia.com/investmen t/20191012173851-21-106514/janjikanreturn-ojk-suspensi-penjualan-reksa-danaminna-padi. diakses tanggal 4 Desember 2019 pada jam 22.42 WIB.

Invovesta Beyond Data. (2019). Resiko Investasi. https://www.infovesta.com/index/learning/l 
earning;jsessionid $=$ C6DE4EAD651433C

D34DC68373E2A3876.NGXA/40. diakses

tanggal 7 Desember 2019 jam 17.50 WIB. 